\title{
Determinants of life satisfaction in Canada: A causal modeling approach
}

\author{
Rose Branch-Allen ${ }^{1}$ and John Jayachandran ${ }^{1 \mathrm{a}}$ \\ ${ }^{1}$ Concordia University of Edmonton, Edmonton, T5B4E4, Alberta, Canada
}

\begin{abstract}
Most research studies on Life Satisfaction/Subjective Wellbeing (SWB) have focused on one main determinant and a variety of social demographic variables to delineate the determinants of life satisfaction. However, very few research studies examine life satisfaction from a holistic approach. The aim of this study was to utilize a holistic approach to construct a causal model and identify major determinants of life satisfaction. This study utilized data from the General Social Survey, with a sample size of 19,597 . Several multiple regression models were run sequentially to estimate standardized path coefficients for the causal model. Overall, above average satisfaction with life was reported by Canadian respondents. Respondents who were female, younger, married, from high socioeconomic status background, born in Canada, very religious, and demonstrated high level of neighborhood interaction had greater satisfaction with life. Similarly, respondents had greater life satisfaction if they had better health, social contact, leisure activities, more time with family and friends, more enjoyment with volunteer activities, and a greater sense of belonging to the community. Our results suggest that a holistic approach is necessary for understanding the causal process of life satisfaction. A significant number of causal connections contradict some of the findings in literature today. We have provided some possible explanations for these anomalies and policy implications.
\end{abstract}

Keywords: Causal model; holistic approach; life satisfaction; sociodemographic variables; subjective well-being.

\section{Introduction}

Canada is a pluralistic, multicultural society with an ethno cultural composition that has been shaped over time by immigrants and their descendants. Although Canada welcomes these immigrants, many will endure severe culture shocks, extreme weather conditions, isolation, barriers to obtaining jobs in their profession, and assimilation difficulties. Despite these life hurdles, surveys consistently report high life satisfaction for all Canadians.

\footnotetext{
${ }^{a}$ Corresponding author: john.jayachandran@concordia.ab.ca
} 
Life satisfaction can be defined as the cognitive component of subjective well-being (SWB) [41]. The terms SWB, life satisfaction and happiness are often used interchangeably [7; 9] and very few research studies have examined life satisfaction from a holistic point of view. In order to comprehend the interaction of socio-psychological factors with life circumstances in producing SWB, we need to understand the causal pathways leading to happiness, understand the processes underlying adaptation to events, and develop theories that explain why certain variables differentially influence the different components of SWB [15]. This study aims, therefore, to utilize a holistic approach to construct a causal model to identify major determinants of life satisfaction.

\section{Literature review}

\subsection{Exogenous concepts}

Empirical studies report, life satisfaction is related to age $[2,4,9,12,13,15,19,28,52$, $63]$, gender [5, 6, 56, 61], marital status [16, 34, 51, 56, 60], and household size [34]. With regard to socio-economic status and life satisfaction, while some studies report a negative $[10,20,21,22,26,27,40]$, others suggest a positive $[11,29,30,33,34]$ relationship.

Studies, in general, report respondents who are religious [24, 46, 62], and live in good neighborhood $[25,39,34]$ seem to have greater satisfaction with life. On the other hand, life satisfaction differentials by ethnicity $[34,42]$ and location $[8,36]$ are complex and often confounded by other socio-economic and demographic factors.

\subsection{Intervenining concepts}

Empirical studies conclude that subjective perceived health is associated with life satisfaction or happiness $[9,14,19,23,43,48]$. It may also reflect certain personality traits and assess individuals' global welfare $[47,58]$. Few recent studies suggest that the mental health dimension is more strongly associated with SWB than the physical health dimension $[18,44]$. Others suggest the existence of a reciprocal relationship between health and happiness i.e., happiness also protects health [14, 54, 59].

Studies report that social contact with friends [38], participation in leisure activities [3, $45]$ and involvement in voluntary groups [17, 49, 55] lead to greater life satisfaction. Similarly, decreased levels of work-family conflict [1, 37] and domestic labour [31], increased quality time with family and friends $[32,53]$, and strong sense of belonging to community tend to improve social contact and life satisfaction [50].

\subsection{Endogenous concept}

Although there is a lack of agreement regarding the definition of life satisfaction [35], this research will adopt the definition as described by [57]: "Life satisfaction is conceived as the degree to which an individual judges the overall quality of his life-as-a-whole favorably."

To the best of our knowledge, very few research studies have examined life satisfaction from a holistic approach. Therefore, the aim of this study was to utilize a holistic approach to construct a causal model and identify major determinants of life satisfaction in Canada.

Based on the literature review above on the possible causal connections between life satisfaction and other factors a causal model was constructed and presented in the causal path of Fig. 1. 


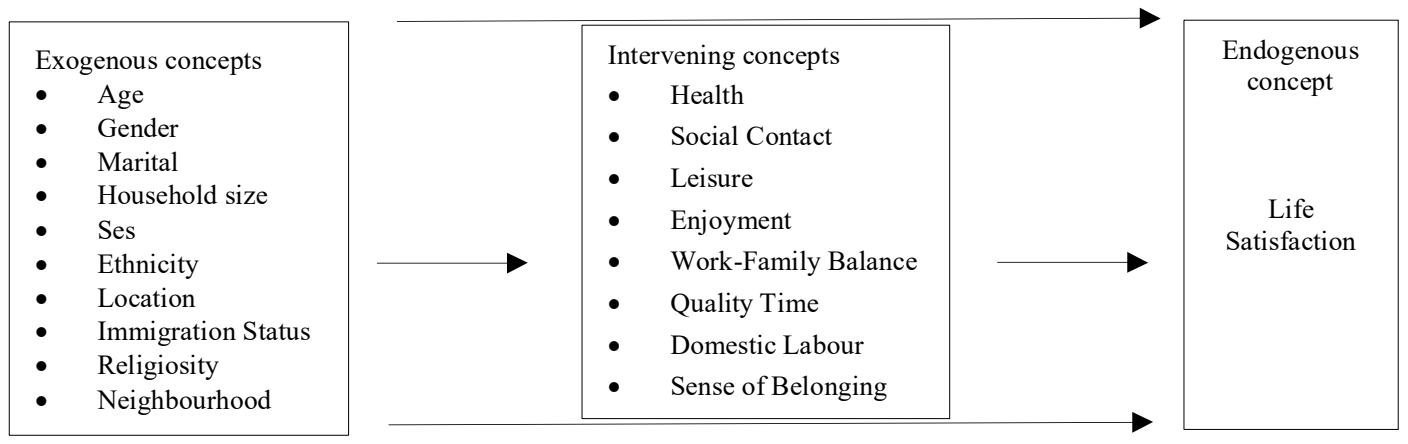

Fig. 1. Proposed Conceptual Framework.

\section{Data, Measures, and Methods}

\subsection{Data}

Data were derived from the General Social Survey (GSS) that gathers data on social subjects in order to monitor changes in the living conditions and well-being of Canadians over time and to provide immediate information on specific social policy issues of current or emerging interest. The target population for the GSS was all persons 15 years of age and over residing in Canada and the sample size was 19,597.

\subsection{Measures}

The concepts for the study were chosen according to both data availability and their relevance to life satisfaction as revealed in the literature. The concept of health was measured by self-report of health, various health problems reported by respondent, sleep problems, and stress. Social contact was measured by socializing of respondent with family members, friends, and others at homes, bars, and clubs. The concept of active leisure was measured by participating in sports, physical exercise or outdoor activity. Whereas the concept of passive leisure measured by activities such as reading books, listening to music , watching T.V or attending various events. The concept of enjoyment included activities enjoyed with family, friends, and volunteer activities. Other concepts in the proposed causal model were measured as provided in the literature.

\section{Methods}

In order to establish causal connections among various factors several multiple regression analyses were performed: (1) first, each intervening concept was regressed on various exogenous concepts as predictors and, (2) an overall model to predict life satisfaction was regressed on both exogenous and intervening concepts simultaneously.

\section{Results}

Table 1 shows that older respondents those who are in poor physical and mental health $(B=.117)$, with less social contact $(B=-.149)$, more time on passive leisure activities $(B=$. 
$171)$ and less time on active leisure activities $(B=-.051)$, less time with family and friends $(\mathrm{B}=-.058)$, less enjoyment with volunteer activities $(\mathrm{B}=-.100)$, and more time on domestic labour $(B=.141)$ tend to have lower satisfaction with life. On the other hand, older respondents, who have a better work-family balance $(B=.064)$, more quality time $(B=$. $196)$, and a greater sense of belongingness to society $(B=-.081)$ seem to have greater satisfaction with life. Similar findings are noted for males, respondents in married or common-law unions, live in large households, and from high SES in this study.

Table 1. Correlations and standardized multiple regression coefficients for the causal model

\begin{tabular}{|c|c|c|c|c|c|c|c|c|c|c|c|}
\hline & health & socont & lepassive & leactive & enjfamfr & enjvol & balwrkfam & qualtime & domlabr & belong & lifesat \\
\hline age & $\begin{array}{l}. \mathbf{1 1 7} \\
(.110)\end{array}$ & $\begin{array}{l}-.149 \\
(-.161)\end{array}$ & $\begin{array}{l}\mathbf{. 1 7 1} \\
(.319)\end{array}$ & $\begin{array}{l}-.051 \\
(-.010)\end{array}$ & $\begin{array}{l}\mathbf{- . 0 5 8} \\
(-.053)\end{array}$ & $\begin{array}{l}-.100 \\
(-.001)\end{array}$ & $\begin{array}{l}.064 \\
(.085)\end{array}$ & $\begin{array}{l}\mathbf{. 1 9 6} \\
(.437)\end{array}$ & $\begin{array}{l}.141 \\
(.092)\end{array}$ & $\begin{array}{l}-. .081 \\
(-.228)\end{array}$ & $\begin{array}{l}-\mathbf{- . 0 2 0} \\
(.060)\end{array}$ \\
\hline gender & $\begin{array}{l}-.094 \\
(-.081)\end{array}$ & & $\begin{array}{l}.081 \\
(.046)\end{array}$ & $\begin{array}{l}.092 \\
(.077)\end{array}$ & & $\begin{array}{l}-.127 \\
(-.148)\end{array}$ & $\begin{array}{l}.044 \\
(.040)\end{array}$ & $\begin{array}{l}. \mathbf{1 4 7} \\
(.058)\end{array}$ & $\begin{array}{l}-.208 \\
(-.196)\end{array}$ & & $\begin{array}{l}-.043 \\
(.003)\end{array}$ \\
\hline marital & $\begin{array}{l}-.053 \\
(-.044)\end{array}$ & $\begin{array}{l}.099 \\
(.166)\end{array}$ & & $\begin{array}{l}-.043 \\
(-.056)\end{array}$ & $\begin{array}{l}. \mathbf{1 7 8} \\
(.208)\end{array}$ & & $\begin{array}{l}.028 \\
(.041)\end{array}$ & $\begin{array}{l}-.027 \\
(-.085)\end{array}$ & $\begin{array}{l}. \mathbf{1 1 7} \\
(.195)\end{array}$ & $\begin{array}{l}-.045 \\
(-.070)\end{array}$ & $\begin{array}{l}\mathbf{0 9 3} \\
(.121)\end{array}$ \\
\hline houssize & & $\begin{array}{l}.088 \\
(.199)\end{array}$ & $\begin{array}{l}-.034 \\
(-.196)\end{array}$ & & $\begin{array}{l}.154 \\
(.203)\end{array}$ & & & $\begin{array}{l}-.115 \\
(-.282)\end{array}$ & $\begin{array}{l}. \mathbf{1 5 9} \\
(.130)\end{array}$ & & \\
\hline ses & & & $\begin{array}{l}-.120 \\
(-.083)\end{array}$ & $\begin{array}{l}-.068 \\
(-.085)\end{array}$ & & & $\begin{array}{l}-.023 \\
(.007)\end{array}$ & $\begin{array}{l}-.175 \\
(-.117)\end{array}$ & $\begin{array}{l}-.046 \\
(-.021)\end{array}$ & & $\begin{array}{l}.026 \\
(.034)\end{array}$ \\
\hline ethnicity & & & & $\begin{array}{l}.039 \\
(.034)\end{array}$ & $\begin{array}{l}.046 \\
(-.016)\end{array}$ & $\begin{array}{l}. \mathbf{0 5 1} \\
(.008)\end{array}$ & $\begin{array}{l}-.060 \\
(-.032)\end{array}$ & & & $\begin{array}{l}.054 \\
(-.046)\end{array}$ & $\begin{array}{l}.044 \\
(.064)\end{array}$ \\
\hline location & $\begin{array}{l}-.025 \\
(-.022)\end{array}$ & & $\begin{array}{l}.024 \\
(-.001)\end{array}$ & $\begin{array}{l}.026 \\
(.008)\end{array}$ & & & $\begin{array}{l}.026 \\
(.009)\end{array}$ & & $\begin{array}{l}-.049 \\
(-.059)\end{array}$ & $\begin{array}{l}.031 \\
(.078)\end{array}$ & \\
\hline yrimmig & & & & & $\begin{array}{l}.042 \\
(.021)\end{array}$ & $\begin{array}{l}.048 \\
(.004)\end{array}$ & & & $\begin{array}{l}-.041 \\
(-.010)\end{array}$ & $\begin{array}{l}.079 \\
(.078)\end{array}$ & $\begin{array}{l}-.021 \\
(-.062)\end{array}$ \\
\hline relgisty & $\begin{array}{l}. \mathbf{0 3 2} \\
(.010)\end{array}$ & $\begin{array}{l}-.021 \\
(-.011)\end{array}$ & $\begin{array}{l}. \mathbf{0 6 3} \\
(-.006)\end{array}$ & & $\begin{array}{l}-.043 \\
(-.041)\end{array}$ & $\begin{array}{l}-.210 \\
(-.218)\end{array}$ & & & & $\begin{array}{l}\mathbf{. 1 6 5} \\
(.228)\end{array}$ & $\begin{array}{l}-.027 \\
(-.098)\end{array}$ \\
\hline neighood & $\begin{array}{l}-.041 \\
(-.012)\end{array}$ & $\begin{array}{l}.023 \\
(-.007)\end{array}$ & $\begin{array}{l}-.030 \\
(.070)\end{array}$ & $\begin{array}{l}. \mathbf{0 3 2} \\
(.012)\end{array}$ & & $\begin{array}{l}.037 \\
(.067)\end{array}$ & $\begin{array}{l}\mathbf{. 0 5 5} \\
(.064)\end{array}$ & & $\begin{array}{l}\mathbf{- . 0 3 5} \\
(.040)\end{array}$ & $\begin{array}{l}-.150 \\
(-.234)\end{array}$ & $\begin{array}{l}.019 \\
(-.107)\end{array}$ \\
\hline lifesat & $\begin{array}{l}-.426 \\
(-.554)\end{array}$ & $\begin{array}{l}. \mathbf{0 2 3} \\
(.082)\end{array}$ & $\begin{array}{l}-.057 \\
(-.037)\end{array}$ & $\begin{array}{l}.012 \\
(.064)\end{array}$ & $\begin{array}{l}.016 \\
(.081)\end{array}$ & $\begin{array}{l}.052 \\
(.150)\end{array}$ & $\begin{array}{l}.097 \\
(.295)\end{array}$ & $\begin{array}{l}. \mathbf{1 7 2} \\
(.302)\end{array}$ & $\begin{array}{l}-.014 \\
(.008)\end{array}$ & $\begin{array}{l}-.167 \\
(-.298)\end{array}$ & \\
\hline
\end{tabular}

*Bold: Standardized multiple regression coefficients (beta); Significance level $=.05$

( ) Pearson's correlation coefficients

Respondents born in North America who spend more time on active leisure activities $(\mathrm{B}=.039)$, more time enjoying with family and friends $(\mathrm{B}=.046)$, more enjoyment with volunteer activities $(B=.051)$, less time on balancing work family life $(\mathrm{B}=-.060)$, a greater sense of belongingness to society $(\mathrm{B}=.054)$, seem to have greater satisfaction with life.

Regardless of respondents' location or immigration status, factors such as poor health, passive leisure activity and domestic labor seem to lower life satisfaction. On the other hand, factors such as active leisure, better work-family balance, and a greater sense of belongingness to society tend to increase satisfaction with life. Religiosity seems to have strong influence on life satisfaction through participation in volunteer activities and sense of belongingness to society.

\section{Discussion}

The exogenous to endogenous results from this causal model concur with most of the findings in Warner Wilson's study [60]. In general, respondents who have greater social contact, participate in active leisure activities, enjoy family time and have more fun and enjoyment, quality time with friends and family, and better balance of work and family life seem to have greater satisfaction with life. These results suggests that a holistic approach is necessary for establishing determinants of life satisfaction and that life satisfaction is not merely comprised of positive or negative effect. The findings also indicate that being healthy, Canadian born; participating in spiritual activities, volunteering and participating 
in leisure activities in addition to living in an urban city with a good job contributes to greater life satisfaction. Some of our results do contradict with findings in literature today.

\section{References}

1. Adams, G. A., King, L. A., \& King, D. W. Relationships of job and family involvement, family social support, and work-family conflict with job and life satisfaction. Journal of Applied Psychology, 81 (4), 411-420,(1996).

2. Baird, B. M., Lucas, R. E., \& Donnellan, M. B., Life Satisfaction Across the Lifespan: Findings From two Nationally Representative Panel Studies. Social Indicators Research, 99 (2), 183-203, (2010).

3. Becchetti, L., Ricca, E. G., \& Pelloni, A., The Relationship Between Social Leisure and Life Satisfaction: Causality and Policy Implications. Social Indicator Research, 108 (3), 453-490, (2012).

4. Blanchflower, D.G., and A.J. Oswald., "Is well-being U-shaped over the life cycle?" Social Science \& Medicine 66: 1733-1749, (2008).

5. Borges, M. A., Levine, J. R., \& Dutton, L. J., Men's and Women's Ratings of Life Satisfaction by Age of Respondent and Age Interval Judged. Sex Roles, 11, (3-4), (1984).

6. Bradburn, N. M., \& Caplovitz, D., Reports on Happiness. In A Pilot Study of Behaviour related to Mental Health (Vol. 3). Chicago: Aldine, (1965).

7. Camfield, L., \& Skevington, S. M., On subjective well-being and quality of life. Journal of Health Psychology, 13(6), 764-775, (2008).

8. Carta, M. G., Aguglia, E., Dell'Osso, L., Sciascio, G., Drago, F., Del Giudice, E., et al. Quality of Life and Urban/Rural Living: Preliminary Results of a Community Survey in Italy. Clinical Practice and Epidemiology in Mental Health. , 8, 169-174, (2012).

9. Conceica o, P \& Bandura, R., Measuring subjective wellbeing: A summary review of the

literature.

http://web.undp.org/developmentstudies/docs/subjective_wellbeing_conceicao_bandur a.pdf. Accessed 29 Oct 2013, (2008).

10. Csikszentmihalyi, M., If we are so rich, why aren't we happy? American Psychologist, 54 (10), 821-827, (1999).

11. Cummins, R. A., Personal Income and Subjective Well-Being: A Review. Journal of Happiness Studies, 1 (2), 133-158, (2000).

12. Diener, E., Subjective well-being. Psychological Bulletin, 95(3), 542-575, (1984).

13. Diener, E., The Collected Works of Ed Diener. The Netherland Springer, (2009).

14. Diener, E., \& Chan, M. Y., Happy people live longer: Subjective well-being contributes to health and longevity: Health benefits of happiness. Applied Psychology: Health and Well-Being, 3(1), 1-43, (2011).

15. Diener, Ed; Suh, Eunkook M.; Lucas, Richard E.; Smith, Heidi L., Subjective wellbeing: Three decades of progress. Psychological Bulletin, Vol 125(2), Mar 1999, 276302, (1999).

16. Diener, E., Gohm, C. L., Suh, E., \& Oishi, S., Similarity of the Relations Between Marital Status and Subjective Well-Being Across the Cultures. Journal of CrossCultural Psychology, 31 (4), 419-436, (2000).

17. Diener, E., \& Seligman, M.E.P., Very happy people. Psychological Science, 13, 81-84, (2002).

18. Dolan, P., \& Metcalfe, R., Valuing health: A brief report on subjective well-being versus preferences. Medical Decision Making, 32(4), 578-582, (2012). 
19. Dolan, P., Peasgood, T., \& White, M., Do we really know what makes us happy? A review of the economic literature on the factors associated with subjective well-being. Journal of Economic Psychology, 29(1), 94-122, (2008).

20. Easterlin, R. A., Does Economic Growth Improve the Human Lot? Some Empirical Evidence. In David P.A. and Reder M.W (Eds.) Nations and Households in Economic Growth. Essays in honour of Moses Abramowitz. New York: Academic Press, (1974)

21. Easterlin, R. A., Will raising the incomes of all increase the happiness of all? Journal of Economic Behavior \& Organization, 27(1), 35-47, (1995).

22. Easterlin, R. A., Income and happiness: Towards a unified theory. The Economic Journal, 111(473), 465-484, (2001).

23. Easterlin, R .A., "Explaining happiness." Proceedings of the National Academy of Sciences 100 (19): 11176-11183, (2003).

24. Ellison, C. G., Gay, D. A., \& Glass, T. A., Does Religious Commitment Contribute to Individual Life Satisfaction? Social Forces, 68 (1), 100-123, (1989).

25. Fernandez, R. M., \& Kulik, J. C., A Multi-level model of Life Satisfaction: Effects of Individual Characteristics and neighbourhood composition. American Sociological Review, 46 (6), 840-850, (1981).

26. Ferrer-i-Carbonell, A., Income and well-being: An empirical analysis of the comparison income effect. Journal of Public Economics, 89(5-6), 997-1019, (2005).

27. Ferrer-i-Carbonell, A., \& Frijters, P., How important is methodology for the estimates of the determinants of happiness? The Economic Journal, 114(497), 641-659, (2004).

28. Frijters, P., \& T. Beatton., "The mystery of the U-shaped relationship between happiness and age." Journal of Economic Behavior \& Organization 82: 525-542, (2012).

29. Frijters, P., Haisken-DeNew, J. P., \& Shields, M., Money does Matter! Evidence from Increasing Real Income and Life Satisfaction in East Germany following Reunification. The American Economic Review. , 94 (3), 730-740, (2004).

30. Georgellis, Y., Tsitsianis, N., \& Yin, Y. P., Personal Values as Mitigating Factors in the Link between Income and Life Satisfaction: Evidence From the European Social Survey. Social Indicators Research, 91 (3), 329-344, (2009).

31. Glass, J., \& Fujimoto, T., Housework, paid work, and depression among husband and wives', Journal of Health and Social Behaviour , 35, 179-191, (1994).

32. Glorieux, I., Minnen, J., \& Van Tienoven, T. P., Spouse "Together Time": Quality Time within the Household. Social Indicators Research, 101 (2), 281-287, (2011).

33. Headley, B., Muffels, R., \& Wooden, M., Money Does Not Buy Happiness: Or does it? A Re-assessment based on the combined effects of Wealth, Income, and Consumption. Social Indicator Research, 87 (1), 65-82, (2008).

34. Hou, F., Keep Up with the Joneses or Keep on as Their Neighbours: Life Satisfaction and Income in Canadian Urban Neighbourhoods. Journal of Happiness Studies. October 2014, Volume 15, Issue 5, pp 1085-1107, (2014).

35. Iverson, R. D., \& Maguire, C., The Relationship Between Job and Life Satisfaction: Evidence from a Remote Mining Community. Human Relations, 53 (6), 807-839, (2000).

36. Kangiuan, L. V., Wang, J., \& Wei, L. V., Study on the Residents Satisfaction Degree in the Urban and Rural Fringe in China - Based on Structural Equation Model. Journal of Cambridge Studies, 5, 2-3, (2010).

37. Lapierre, L. M., Spector, P. E., Allen, T. D., Poelmans, S., Cooper, C. L., O'Driscoll, M. P., et al., Family Supportive Organization Perceptions, Multiple Dimensions of Work-Family Conflict, and Employee Satisfaction: A test of Model Across Five Samples. Journal of Vocational Behaviour, 780, 92-106, (2008). 
38. Lee, G. R., Marital Satisfaction in Later Life: The Effects of Nonmarital Roles. Journal of Marriage and the Family, 50 (3), 775-783, (1988).

39. Leyden, K. M., Goldberg, A., \& Michelbach, P., Understanding the Pursuit of Happiness in Ten Major Cities. Urban Affairs Review, 47 (6), 861-888, (2011).

40. Luttmer, E. F., Neighbors as negatives: Relative earnings and well-being. The Quarterly Journal of Economics, 120(3), 963-1002, (2005).

41. Martikainen, L., The Many Faces of Life Satisfaction among Finnish Young Adults. Journal of Happiness Studies, 10 (6), 721-737, (2008).

42. Mata, F., A look at life Satisfaction and Ethnicity in Canada. Canadian Ethnic Studies, 34 (1), P51-63, (2002).

43. Michalos, A. C., Zumbo, B. D., \& Hubley, A., Health and the Quality of Life. Social Indicators Research, 51, 245-286, (2000).

44. Mukuria, C., \& Brazier, J., Valuing the EQ-5D and the SF-6D health states using subjective wellbeing: A secondary analysis of patient data. Social Science \& Medicine, 77, 97-105, (2013).

45. Newman, D.B., Louis Tay., \& Ed Diener., Leisure and Subjective Well-Being: A Model of Psychological Mechanisms as Mediating Factors. Journal of Happiness Studies Volume 15, Issue 3 pp. 555-578, (2014).

46. Okulicz-Korzaryn, A., Does Religion Makes Us Unhappy? Mental Health, Religion and Culture. , 14 (10), 1036-1076, (2011).

47. Oshio, T., \& M. Kobayashi., "Income inequality, perceived happiness, and self-rated health: Evidence from nationwide surveys in Japan." Social Science \& Medicine 70: 1358-1366, (2010).

48. Palmore, E., \& Luikart, C., Health and Social Factors Related to Life Satisfaction. Journal of Health and Social Behaviour, 13 (1), 68-80, (1972).

49. Pinquart, M., \& Sörensen, S., Influences of socio-economic status, social network, and competence on subjective well-being in later life: A meta-analysis. Psychology and Aging, 15, 187-224, (2000).

50. Prezza, M., Roberti, A. M., \& Tedeschi, G., Sense of Community Referred to the Whole Town: Its Relations with Neighbhouring, Loneliness, Life Satisfaction and Area of Residence. Journal of Community Psychology, 29 (1), 29-52, (2001).

51. Ren, Q., \& Treiman, D. J., Living Arrangements of the Elderly in China and Consequences for their Emotional Well-Being. Research, University of Michigan. Institute for Social Research, (2014).

52. Ryff, C. D., In the Eye of the Beholder: Views of Psychological Well-Being Among Middle Aged and older Adults. Journal of Gerontology: Psychology and Aging. , 4 (2), 195-210, (1989).

53. Shapiro, A., \& Keyes, C. L., Marital Status and Social Well-Being: Are the married always better off? Social Indicators Research, 88 (2), 329-346, (2008).

54. Siahpush, M., M. Spittal, and G.K. Singh., "Happiness and Life Satisfaction Prospectively Predict Self-Rated Health, Physical Health, and the Presence of Limiting, Long-Term Health Conditions." American Journal of Health Promotion 23 (1): 18-26, (2008).

55. Tkach, C., \& Lyubomirsky, S., How do people pursue happiness? Relating personality, happiness-increasing strategies, and well-being. Journal of Happiness Studies, 7 (2), 183-225, (2006).

56. Tovar-Murray, D., Social Health and Environmental Quality of Life: Their Relationship to Positive Physical Health and Subjective Well-Being in a Population of Urban African Americans. The Western Journal of Black Studies, 34 (3), (2010). 
57. Veenhoven, R., Questions on Happiness: Classical Topics, Modern Answers, and Blind Spots. (F. Stack, M. Argyle, \& N. Schwartz (Eds.), Eds.) Elmsford, New York: Pergamon Press, (1991).

58. Veenhoven, R., "The four qualities of life." Journal of Happiness Studies 1: 1-39, (2000).

59. Veenhoven, R., "Healthy happiness: effects of happiness on physical health and the consequences for preventive health care." Journal of Happiness Studies 9: 449-469, (2008).

60. Wilson, W. R., Correlates of Avowed Happiness. Psychological Bulletin, 67 (4), 294306, (1967).

61. Wood, W., Rhodes, N., \& Whelan, M., Sex Differences in Positive Well-Being: A Consideration of Emotional Style and Marital Status. Psychological Bulletin 106 (2), 249-269, (1989).

62. Witter, R. A., William, S. A., Okun, M. A., \& Haring, M. J., Religion and Subjective Well-Being in Adulthood: A Quantitative Synthesis. Review of Religious Research, 26 (4), 332-342, (1985).

63. Zhang, L. J., \& Leung, P., Mode Rating effects of gender and age on relationship between self-esteem and life satisfaction in mainland China. International Journal of Psychology, 37 (2), 83-91, (2002). 